Research Article

\title{
Genetic Differentiation for Gene Diversity among Pearl Millet (Pennisetum glaucum (L.) R. Br.) Landraces As Revealed by SSR Markers
}

\author{
Lardia Ali Bougma $\left(\mathbb{D},{ }^{1}\right.$ Mahamadi Hamed Ouédraogo $\left(\mathbb{D},{ }^{1}\right.$ Adjima Ouoba $\left(\mathbb{D},{ }^{2}\right.$ \\ Abdou Azaque Zouré $\mathbb{D},{ }^{3}$ Nerbéwendé Sawadogo $\mathbb{D},{ }^{1}$ and Mahamadou Sawadogo $\mathbb{D}^{1}$ \\ ${ }^{1}$ Département de Biologie et Physiologie Végétales, Université Joseph Ki-Zerbo, BP 7021, Ouagadougou 03, Burkina Faso \\ ${ }^{2}$ Centre Universitaire de Ziniaré, Université Joseph Ki-Zerbo, Ouagadougou, Burkina Faso \\ ${ }^{3}$ Institut de Recherche en Sciences de La Santé (IRSS/CNRST), 03 BP7192, Ouaga 03, Burkina Faso
}

Correspondence should be addressed to Lardia Ali Bougma; alilardia@gmail.com and Nerbéwendé Sawadogo; nerbewende@ yahoo.fr

Received 29 May 2021; Revised 4 August 2021; Accepted 28 August 2021; Published 21 September 2021

Academic Editor: Maria Serrano

Copyright (c) 2021 Lardia Ali Bougma et al. This is an open access article distributed under the Creative Commons Attribution License, which permits unrestricted use, distribution, and reproduction in any medium, provided the original work is properly cited.

\begin{abstract}
Pearl millet (Pennisetum glaucum) is one the most important crops in Burkina Faso. Knowledge of the genetic parameters of different pearl millet landraces grown in Burkina Faso is of great importance for improvement and breeding programs of pearl millet. In this study, 20 pairs of SSR markers were used to compare and analyze the genetic diversity of 86 landrace populations. Results show a total of 67 alleles detected and each locus varies between 2 and 6 with an average of 4 alleles per marker. The probability to having two different alleles per locus was 0.61 . The values of genetic diversity parameters of pearl millet populations from the northern region of the country were higher than those from the others regions. The analysis indicates that, over time, alleles are lost and new alleles are added. Analysis of molecular variance showed genetic variation was primarily a function of differences in cultivated populations. Most pairwise $\mathrm{F}_{\mathrm{ST}}$ comparisons between provenances were at a statistically significant level. Our study will provide a scientific basis for the effective management and utilization of germplasm resources of pearl millet populations.
\end{abstract}

\section{Introduction}

In Burkina Faso, economy is largely based on crop production and livestock, which engage $90 \%$ of the workforce and contribute to $39 \%$ of the gross domestic product [1]. Pearl Millet (Pennisetum glaucum) is one the most important cereals where daily consumption per capita is around 70 gr [2]. Its growing areas have increased continuously, and it is cultivated in traditional farming systems. The greatest morphological diversity of this species is found in West Africa, south of the Sahara Desert, and north of the forest zone [3, 4]. Because of its versatility, pearl millet is still a fundamental component of production systems and diets in Sahelian countries, where many prefer it to sorghum for culinary purposes.
The situation of pearl millet landraces is becoming very serious. Climate change impacts this resource. Its conservation represents a high priority for the country. Now, strategies for managing resources have resulted in the use of a molecular tool $[5,6]$. At present, molecular characterization is becoming the capital tool in methods and programs for improving agricultural genetic resources [7]. The importance of microsatellite markers is to deepen investigation knowledge of genetic diversity. According to the work in [8], the use of molecular markers has overcome limitations of morphological markers in characterization by identifying variations directly from DNA. Because of their high degree of polymorphism, microsatellites have been used in the study of genetic diversity and in the evolutionary history of pearl millet by several authors [5, 9-11]. 
Polymorphism of pearl millet is widely studied throughout the world. However, assessing the genetic diversity of landrace pearl millet in Burkina Faso may provide a better understanding of how to insert landrace pearl millet in a breeding national program. The present study seeks to highlight the genetic diversity of pearl millet landraces using codominant markers (SSRs). Therefore, the aims of the present study are (1) to estimate the level of genetic diversity of pearl millet landraces in Burkina Faso; (2) to assess the distribution of allelic frequencies between geographic regions; and (3) to find potential genetic groups of cultivated pearl millet.

\section{Materials and Methods}

2.1. Plant Material and Microsatellite Markers Used. In 2014, samples were collected in three agroclimatic zones in different villages of Burkina Faso including 10 landraces of pearl millet from the east zone, 36 landraces from north, 7 landraces from west, and 33 landraces from south (Figure 1). This plant material had been previously used for morphophysiological diversity assessment during the 2015 rainy season in Burkina Faso [12].

A set of 20 microsatellites (Table 1) specific to Pennisetum glaucum (L.) R. Br. and extremely polymorphic was chosen for this study $[5,13]$.

\subsection{Methods}

2.2.1. DNA Extraction. Seeds of each accession were sown in pots in a green house in 2016 at the Life and Earth Sciences Training and Research Unit of the University of Joseph KIZERBBO. Fresh leaves eighteen (18) days old were collected and packaged in aluminum foil. DNA from each accession plant was extracted by the method in [14]. $20 \mathrm{mg}$ of each sample was ground to which $2000 \mu \mathrm{l}$ of Tris-EDTA-Sorbitol (TES) buffer was added. After centrifugation $(10000 \mathrm{~g}$, $10 \mathrm{~min}, 4^{\circ} \mathrm{C}$ ), the DNA was precipitated from the supernatant using $750 \mu \mathrm{l}$ MATAB (Mixed Alkyl Trimethyl Ammonium Bromide) and the samples were run in a water bath at $65^{\circ} \mathrm{C}, 2 \mathrm{~h} 30 \mathrm{~min}$ with manual shaking of the tubes every $15 \mathrm{~min} .750 \mu \mathrm{l}$ chloroform and iso-amyl alcohol (CIAA, 24 : 1) was brought into the tubes and recentrifuged $(10000 \mathrm{~g}$, $\left.4^{\circ} \mathrm{C}, 10 \mathrm{~min}\right)$. Three levels of separations were obtained, and for each sample, the supernatant was taken and put into a tube. $750 \mu \mathrm{l}$ of iso-propanol stored at $-20^{\circ} \mathrm{C}$ was added to the volume $(1: 1)$ to precipitate the total DNA. After centrifugation $\left(10000 \mathrm{~g}, 4^{\circ} \mathrm{C}, 10 \mathrm{~min}\right)$, the supernatant was precipitated. The tubes were dried for $1 / 2$ day at room temperature and stored in Tris-EDTA buffer $\left(\mathrm{TE},-20^{\circ} \mathrm{C}\right)$.

2.2.2. PCR Amplification. The method used was similar to that in $[9,10]$. PCR amplification was performed in a total reaction volume of $20 \mu \mathrm{l}$ containing $2 \mu \mathrm{l}$ of genomic DNA, $2.5 \mu \mathrm{l}$ of buffer, $0.5 \mu \mathrm{l}$ of each primer (sense and reverse), $0.5 \mu \mathrm{l}$ of dNTPs, and $0.2 \mu \mathrm{l}$ of Taq DNA polymerase. PCR program consisted of five steps: (1) initial DNA denaturation of $94^{\circ} \mathrm{C}$ for $3 \mathrm{~min},(2)$ denaturation of $94^{\circ} \mathrm{C}$ for $30 \mathrm{~s}$, (3) primer hybridization for $30 \mathrm{~s}$ (dependent on primer temperature), (4) elongation at $72^{\circ} \mathrm{C}$ for $1 \mathrm{~min}$ and repeat of 35 cycles for steps 2,3 , and 4 , and (5) final elongation at $72^{\circ} \mathrm{C}$ for $7 \mathrm{~min}$.

2.2.3. Agarose Gel Migration. For the migration, $10 \mu \mathrm{l}$ of each PCR sample was put into each well on $3 \%$ agarose gel. A molecular size standard between 50 and 500 bp was placed as control. The size of the different alleles could be determined very accurately. PCR products were separated under a voltage of $80 \mathrm{~V}$ for $1 \mathrm{~h} 30 \mathrm{~min}$. DNA fragments were separated during migration according to their length, with shorter fragments migrating faster than longer fragments. The gel was transferred to ethidium bromide solution (5\%) for $20 \mathrm{~min}$ and washed with distilled water for about $3 \mathrm{~min}$. The fragments were visualized using a transilluminator equipped with a camera that detects fluorescent molecules present on the amplified fragments.

2.3. Genetic Diversity Parameters. The degree of polymorphism at each locus was assessed through the Polymorphism Information Content (PIC) using the formula [15] $\mathrm{PIC}=1-\sum \mathrm{P} 2 i j$ or relative frequency of the $j$ th allele for the $i$ th locus of the set of all alleles. Furthermore, we estimated for each locus the following descriptors of genetic diversity: total number of alleles $(A)$, number of rare alleles $\left(\mathrm{A}^{\mathrm{r}}\right.$, less than $5 \%)$, number of private alleles $\left(\mathrm{A}^{\mathrm{pr}}\right)$, effective number of alleles (Ae), allelic richness ( $\left.\mathrm{A}^{\text {rich }}\right)$, and Shannon index (I). The expected, heterozygosity $\left(H_{\mathrm{e}}\right)$ was calculated according to the work in [16]. The gene diversity was calculated as $n$ / $(n-1)\left(1-q_{i}^{2}-\mathrm{Ho} / 2 n\right)$, where $n$ is the number of individuals, qi is the frequency of the $i$ th allele, and Ho is the number of observed heterozygotes. For genetic differentiation between the groups, $\mathrm{F}$ statistics $\left(\mathrm{F}_{\mathrm{ST}}\right)$ were estimated according to the work in [17] and genetic distance per pair $\mathrm{F}_{\mathrm{ST}}$ was calculated by the method of [18].

2.4. Data Analysis. Analysis of genetic data was performed using GenAlex 6.501 software used for the calculations of these different molecular genetic diversity parameters. Genetix and DaRwin software were used for the construction of the phylogenetic tree of diversity by the neighborjoining algorithm method.

\section{Results}

\subsection{Overall Genetic Diversity of the Millet Population}

3.1.1. Number of Alleles Observed Per Marker. A total of 67 different alleles were detected using 18 polymorphic microsatellites (Table 2). The number of alleles ranged from 2 for markers Xpsmp 2236, Xpsmp 2231, and Xpgird 49 to 6 for markers Xpsmp2001 and Xpsmp 2273 with an average of 3.72 alleles per marker. The average number of effective alleles found was 3.13. The difference between these two averages is explained by the presence of rare alleles (Ar), whose frequency is less than $5 \%$. 


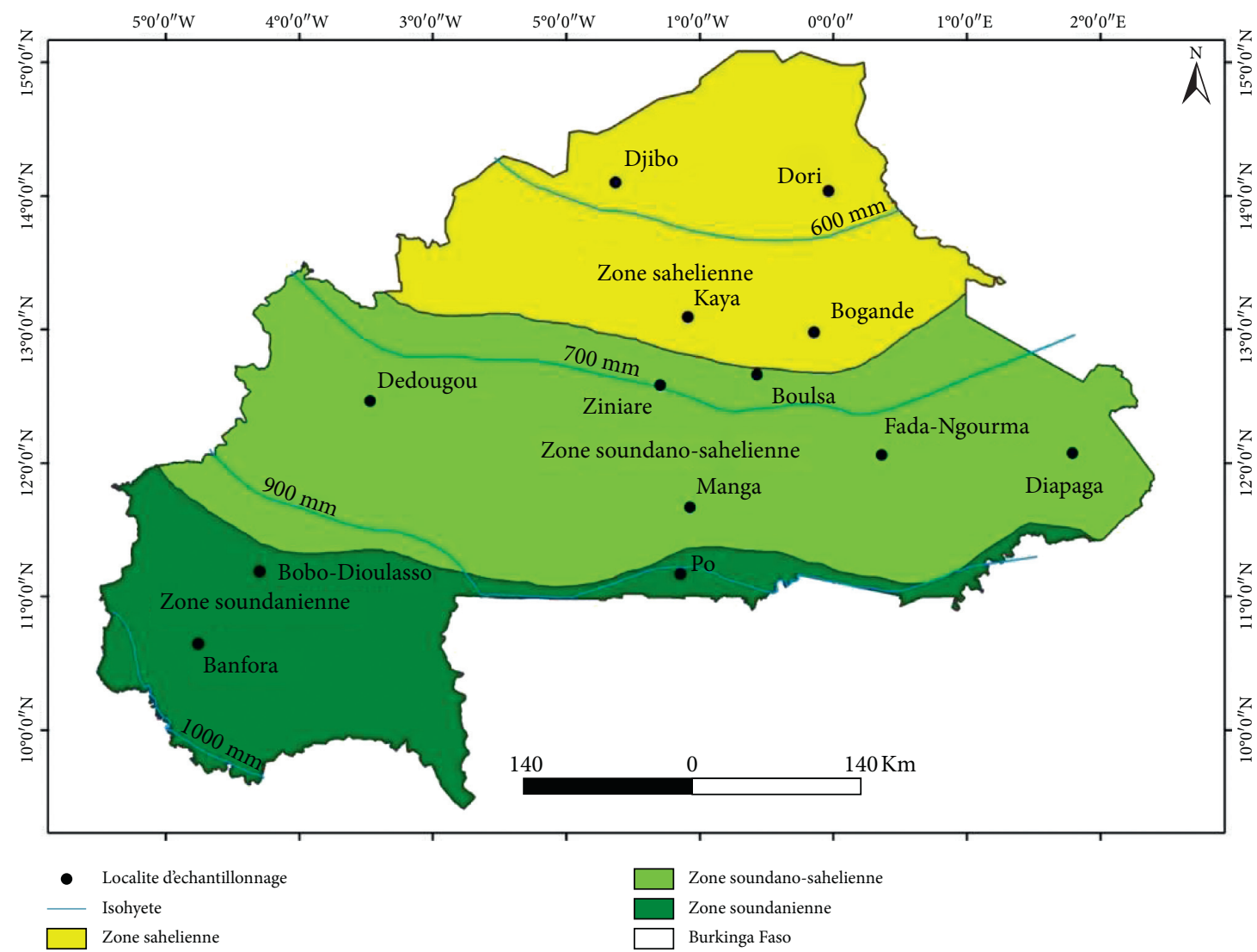

FIGURE 1: Geographic distribution of the pearl millet accessions used in this study.

3.1.2. Polymorphism Information Content (PIC) and Shannon Index (I). The PIC values in the pearl millet population ranged from 0.11 (Xpsmp 2027) to 0.99 (Xpsmp 2263) with an average of 0.68 (Table 2 ). $83 \%$ of the primers revealed a number of alleles from 3 to 6 with a PIC between 0.57 and 0.99 per locus. The collection, with 7 rare alleles out of 67 different alleles detected, has a polymorphism rate $(\mathrm{P} \%)$ of $97.5 \%$. The number of specific alleles estimated by the Shannon index showed a specific richness ranging from 0.44 to 1.45. Primers Xpsmp2236, Xpsmp2263, Xpsmp2231, Xpsmp2027, and Xpgird49 showed low Shannon index probability (Table 2).

3.1.3. Expected Heterozygosity ( $\mathrm{He})$. The primers studied all showed expected heterozygosity values different from zero. The allele sizes were observed to range from $500 \mathrm{bp}$ to $50 \mathrm{bp}$ (Figure 2). The distribution of markers according to their degree of heterozygosity is given in Table 2, showing the existence of a large variability among markers. An average observed heterozygosity ( $\mathrm{He}$ ) of 0.61 was obtained with values ranging from 0.21 (Xpsmp 2027) to 0.98 (Xpsmp 2273) with an average of 0.61 .

3.1.4. Rare Alleles ( $\left.f^{<} 5 \%\right)$. Seven alleles showed a frequency of less than $5 \%$ (Table 2). If this number alleles is high for a given marker, it puts the allelic richness of the marker into perspective. The number frequency of alleles is lower, ranging from 0 to 2 , the maximum being reached with the markers having the highest number of observed alleles (Xpsmp 2273 and Xpsmp 2001).

3.2. Genetic Diversity of Accessions between Different Latitudes. Table 3 compares the genetic diversity of the accessions collected between different degrees of latitude. It can be seen that agroclimatic differences have a weak effect on the average genetic diversity studied. Sixty-seven (67) different alleles are detected with average allele number per marker according to latitude degree varying from 2.44 (latitude $14^{\circ}$ ) to 3.22 (latitude $11^{\circ}$ ). Latitude $10^{\circ}$ had the lowest number of alleles ( 37 alleles). Accessions collected in latitude degrees $12^{\circ}$ and $14^{\circ}$ had relatively fewer alleles (44-49). The highest allele number was observed at $11^{\circ}$ and $13^{\circ}$ North latitude (58-55). These accounted for $87 \%$ of the total allelic diversity. The number of effective alleles for $12^{\circ}$ latitude was nearly similar to that obtained for $10^{\circ}$ and $13^{\circ}$ latitudes but slightly higher than that for $14^{\circ}$ and $11^{\circ}$ latitudes. In addition, the accessions of latitude degrees $10^{\circ}$ and $11^{\circ}$ with a relatively low Shannon index reveal a better allelic originality. The private alleles found were 5 , revealing that these accessions are likely to possess gene originality to be compared with other accessions. These alleles are from accessions from $10^{\text {th }}, 11^{\text {th }}$, and $13^{\text {th }}$ degree North latitude areas. The analysis also showed 4 others rare alleles, present only in the population of accessions from latitudes $11^{\circ}, 12^{\circ}$, and $13^{\circ}$. Statistics based on expected heterozygosity revealed 
TABLE 1: Microsatellite markers used.

\begin{tabular}{|c|c|c|c|c|}
\hline Markers & Sequences (F/R) & Motif & $\mathrm{T}^{\circ} \mathrm{C}$ opt & PCR \\
\hline Xpsmp2001 & $\begin{array}{l}\text { CATGAAGCCAATTAGGTCTC } \\
\text { ACCATCTGACTTGTTCTTATCC }\end{array}$ & $(\mathrm{CT})_{8}(\mathrm{CA})_{48}$ & 50 & 304 \\
\hline Xpsmp2008 & $\begin{array}{l}\text { GATCATGTTGTCATGAATCACC } \\
\text { ACACTACACCTACATACGCTCC }\end{array}$ & $(\mathrm{GT})_{37}$ & 60 & 238 \\
\hline Xpsmp2030 & $\begin{array}{l}\text { ACCAGAGCTTGGAAATCAGCAC } \\
\text { CATAATGCTTCAAATCTGCCACAC }\end{array}$ & (CA)11(GA) 10 & 50 & 107 \\
\hline Xpsmp2043 & $\begin{array}{c}\text { TCATATTCTCCTGTCTAAAACGTC } \\
\text { ACAAATCGTACAAGTTCCACTC }\end{array}$ & (CA)13 (GA)6 & 55 & 192 \\
\hline Xpsmp2063 & $\begin{array}{c}\text { GAGCACATGAAATAGGAAG } \\
\text { AAGGTAGTTATAGTTAGCTTGATC }\end{array}$ & (AC)22(AT)5 & 55 & 166 \\
\hline Xpsmp2071 & $\begin{array}{l}\text { TTGCAGTCCCACGAATTATTTG } \\
\text { CTATGAATTTATAATCCTGATACT }\end{array}$ & (CA)14 & 55 & 181 \\
\hline Xpsmp2076 & $\begin{array}{l}\text { GGAATAGTATATTGGCAAAATGTG } \\
\text { ATACTACACCTGTAAGCATTGTC }\end{array}$ & (AC) 15 & 50 & 161 \\
\hline Xpsmp2267 & $\begin{array}{l}\text { GGAAGGCGTAGGGATCAATCTCAC } \\
\text { ATCCACCCGACGAAGGAAACGA }\end{array}$ & (GA)16 & 55 & 241 \\
\hline Xpsmp2090 & $\begin{array}{l}\text { AGCAGCCCAGTAATACCTCAGCTC } \\
\text { AGCCCTAGCGCACAACACAAACTC }\end{array}$ & (CT) 12 & 55 & 178 \\
\hline Xpsmp2248 & $\begin{array}{l}\text { TCTGTTTGTTTGGGTCAGGTCCTTC } \\
\text { CGAATACGTATGGAGAACTGCGCATC }\end{array}$ & (TG) 10 & 55 & 167 \\
\hline Xpsmp2237 & $\begin{array}{c}\text { TGGCCTTGGCCTTTCCACGCTT } \\
\text { CAATCAGTCCGTAGTCCACACCCCA }\end{array}$ & $(\mathrm{GT}) 8$ & 50 & 233 \\
\hline Xpsmp2231 & $\begin{array}{l}\text { TTGCCTGAAGACGTGCAATCGTCC } \\
\text { CTTAATGCGTCTAGAGAGTTAAGTTG }\end{array}$ & (TG)12GG(TA)4 & 52 & 229 \\
\hline Xpsmp2027 & $\begin{array}{l}\text { AGCAATCCGATAACAAGGAC } \\
\text { AGCTTTGGAAAAGGTGATCC }\end{array}$ & $(\mathrm{GT}) 31$ & 50 & 273 \\
\hline Xpsmp2236 & $\begin{array}{l}\text { ATAAGTGGGACCCACATGCAGCAC } \\
\text { CGAAAGACTAGCAAAATTGCGCCTTC }\end{array}$ & (TG)4(GT)4 & 54 & 265 \\
\hline Xpsmp2261 & $\begin{array}{c}\text { AATGAAAATCCATCCCATTTCGCC } \\
\text { CGAGGACGAGGAGGGCGATT }\end{array}$ & (GA)16 & 54 & 193 \\
\hline Xpsmp2263 & $\begin{array}{l}\text { AAAGTGAATACGATACAGGAGCTGA } \\
\text { G CATTTCAGCCGTTAAGTGAGACAA }\end{array}$ & (AG)33 & 50 & 238 \\
\hline Xpsmp2266 & $\begin{array}{l}\text { CAAGGATGGCTGAAGGGCTATG } \\
\text { TTTCCAGCCCACACCAGTAATC }\end{array}$ & (GA)17 & 58 & 181 \\
\hline Xpsmp2273 & $\begin{array}{l}\text { AACCCCACCAGTAAGTTGTGCTGC } \\
\text { GATGACGACAAGACCTTCTCTCC }\end{array}$ & (GA)12 & 56 & 169 \\
\hline Xpgird13 & $\begin{array}{l}\text { CAGCAGCGAGAAGTTTAGCA } \\
\text { GCGTAGACGGCGTAGATGAT }\end{array}$ & $(\mathrm{AGC}) 8$ & 60 & 250 \\
\hline Xpgird49 & $\begin{array}{l}\text { AGCTCCTCGACGGAGAAAGT } \\
\text { GACGGTGTCGACGAAGATG }\end{array}$ & (CGG)6 & 52 & 190 \\
\hline
\end{tabular}

a genetic diversity (He) of 0.42 for the accessions from $14^{\circ}$ North latitude was significantly low compared to other latitude degrees, showing low intrapopulation diversity in this climatic gradient.

3.3. Genetic Diversity of Landraces According to the Geographic Region. The organization of the collection according to the individual contributions of each geographic region to the total diversity is presented in Table 4 . There were nonsignificant differences between regions for the effective number of alleles, which ranged from 2.75 (west) to 3.29 (south). This effective number of alleles is nearly similar for that of the east, north, and south regions. Gene diversity (He) for regional contributions show little variation among regions except for that of the West region (0.37). The number of alleles per locus between geographic regions varied from 2.72 (west) to 3.33 (south). Rare alleles were present in accessions from both the north and south. Statistics based on the number of alleles found indicate that two regions, namely, the north and south, can alone represent the total allelic diversity of the collection (100\%).

3.4. Structuring of Accessions of Genetic Diversity. The analysis showed that genetic structuring is weakly related to the factor degree of latitude or geographic regions. This result is revealed by the existence of a nonsignificant genetic differentiation of accessions for the factors interdegrees of latitude and interregions (Tables 5 and 6 ). Indeed, the genetic distance between $14^{\circ}$ latitude and each of the other four latitudes is greater than the observed difference between each of the four latitudes. However, the highest minimum Nei distance was observed between $10^{\circ}$ and $14^{\circ}$ latitude (0.196). In addition, the extreme geographic genetic distances of the accessions were observed between the east and 
TABLE 2: Genetic diversity statistics of pearl millet germplasm collected from Burkina Faso.

\begin{tabular}{|c|c|c|c|c|c|c|}
\hline Primers & Allele number $\left(\mathrm{A}^{\mathrm{t}}\right)$ & Efficient allele $\left(\mathrm{A}_{\mathrm{e}}\right)$ & Gene diversity $(\mathrm{He})$ & Shannon index (I) & PIC & Rare allele $\left(\mathrm{A}^{\mathrm{r} *}\right)$ \\
\hline Xpsmp 2001 & 6 & 5.53 & 0.94 & 1.45 & 0.89 & 2 \\
\hline Xpsmp 2008 & 4 & 3.62 & 0.50 & 0.89 & 0.47 & 1 \\
\hline Xpsmp 2030 & 3 & 2.79 & 0.50 & 0.79 & 0.74 & 1 \\
\hline Xpsmp 2043 & 4 & 3.39 & 0.80 & 1.16 & 0.57 & 0 \\
\hline Xpsmp 2236 & 2 & 2.37 & 0.27 & 0.44 & 0.15 & 0 \\
\hline Xpsmp 2248 & 4 & 3.51 & 0.87 & 1.24 & 0.72 & 0 \\
\hline Xpsmp 2063 & 4 & 3.38 & 0.80 & 1.17 & 0.49 & 0 \\
\hline Xpsmp 2071 & 3 & 2.58 & 0.44 & 0.74 & 0.98 & 0 \\
\hline Xpsmp 2076 & 5 & 4.22 & 0.71 & 1.08 & 0.66 & 1 \\
\hline Xpsmp 2263 & 4 & 2.38 & 0.32 & 0.59 & 0.99 & 0 \\
\hline Xpsmp 2237 & 4 & 3.79 & 0.95 & 1.33 & 0.84 & 0 \\
\hline Xpsmp 2231 & 2 & 1.46 & 0.32 & 0.50 & 0.96 & 0 \\
\hline Xpsmp 2027 & 3 & 2.25 & 0.21 & 0.56 & 0.11 & 0 \\
\hline Xpsmp 2261 & 4 & 3.54 & 0.86 & 1.23 & 0.83 & 0 \\
\hline Xpsmp 2266 & 4 & 3.07 & 0.67 & 1.01 & 0.76 & 0 \\
\hline Xpsmp 2263 & 3 & 3.66 & 0.49 & 0.84 & 0.78 & 1 \\
\hline Xpsmp 2273 & 6 & 4.84 & 0.98 & 1.40 & 0.82 & 1 \\
\hline Xpgird 49 & 2 & 1.61 & 0.38 & 0.57 & 0.44 & 0 \\
\hline Mean & 3.72 & 3.22 & 0.61 & 0.94 & 0.68 & 0.39 \\
\hline $\mathrm{SD}$ & 1.18 & 1.04 & 0.25 & 0.33 & 0.26 & - \\
\hline
\end{tabular}

PIC- polymorphism information content, SD- standard deviation.

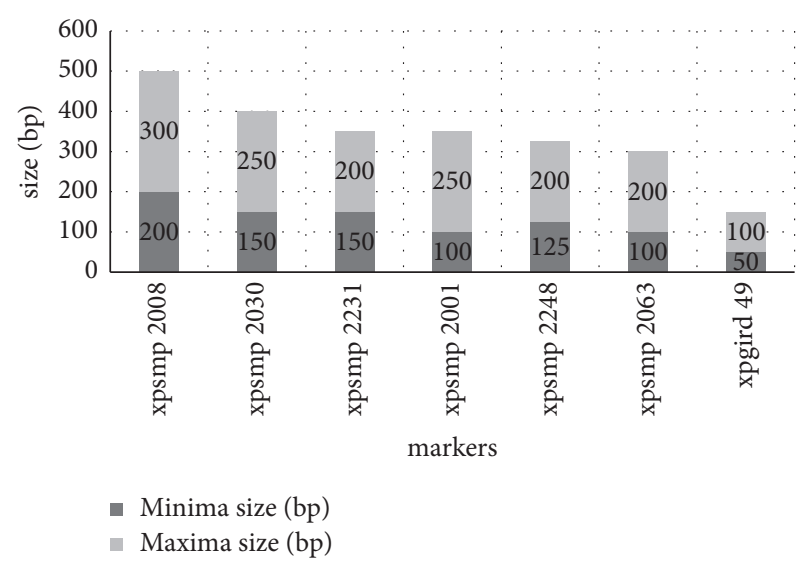

FIGURE 2: SSR marker allele size revealed.

the west $(0.120)$. The correlation studied between the Nei genetic distance matrix and the geographic distance matrix between populations was found to be highly significant with Mantel's test at the $5 \%$ threshold $(r=0.83, P<0.05)$ showing molecular diversity related to geographic distances between cultivated accessions. The analysis indicates that cultivars at $14^{\circ}$ latitude are genetically more separated from cultivars at other latitudes. The results presented in Tables 7 and 8 show, respectively, that the genetic similarity index of accessions remains high in each of the factors studied.

\subsection{Organization of Genetic Diversity}

3.5.1. Distance Table Factor Analysis (DTA). The 1/2 plane axe explained $15.96 \%$ and $10.55 \%$ of the genetic variation, respectively (Figure 3). Analysis summarizes existing relationships between the five populations of accessions from different latitudes. In this $1 / 2$ plane, the factorial analysis on the genetic distance table shows a clustering of accessions around the central axis, reflecting the low genetic diversity among the studied accessions. It was noted there is no clear pattern of observed structure among the accessions at different latitudes. However, a majority of accessions were located in the upper part of the biplot of the factor analysis. These accessions show a better relationship compared to those located in the lower part of the biplot. The analysis indicates that most of the accessions at $14^{\circ}$ latitude are included in the accessions at $13^{\circ}$ latitude. The trend of genetic diversity consisting primarily of two blocks emerged from this analysis.

3.5.2. Racial Structuring of Landraces. Racial structuring resulting from the pairwise comparison of the genetic distances between the 86 accessions according to neighborjoining is represented by the dendrogram (Figure 4). The different accessions were classified within the three groups. Indeed, the dendrogram indicated a classification without clear grouping criteria. However, three main groups are observed from which secondary subgroups diverge. These three genetic populations $(K=3)$ showed structuring independent of geographic regions and climatic gradients:

(i) Genetic group A from geographical regions south, east, and north represents a part of early accessions from the north and semiearly from the south and east has adapted to several environments.

(ii) Genetic group B contains a part of accessions of all the geographical regions. This group gathers the majority of semiearly accessions from all geographical regions.

(iii) Genetic group $\mathrm{C}$ is subdivided into three genetic subpopulations $\mathrm{C} 1, \mathrm{C} 2$, and $\mathrm{C} 3$. The most of the accessions are represented in this group. The 
TABLE 3: Genetic diversity of accessions from different latitude degrees, assessed by SSR markers.

\begin{tabular}{lccccccccc}
\hline $\begin{array}{l}\text { Degree of } \\
\text { latitudes }\left(^{\circ}\right)\end{array}$ & $\begin{array}{c}\text { Accessions } \\
\text { number }\end{array}$ & $\begin{array}{c}\text { Allele } \\
\text { number }\left(\mathrm{A}^{\mathrm{t}}\right)\end{array}$ & $\begin{array}{c}\text { Mean/ } \\
\text { markers }\end{array}$ & $\begin{array}{c}\text { Effective } \\
\text { allele }\left(\mathrm{A}_{\mathrm{e}}\right)\end{array}$ & $\begin{array}{c}\text { Gene } \\
\text { diversity }(\mathrm{He})\end{array}$ & $\begin{array}{c}\text { Shannon } \\
\text { index }(\mathrm{I})\end{array}$ & $\begin{array}{c}\text { Rare } \\
\text { allele }\left(\mathrm{A}^{\mathrm{r}}\right)\end{array}$ & $\begin{array}{c}\mathrm{P} \\
(\%)\end{array}$ & $\begin{array}{c}\text { Private } \\
\text { allele }\left(\mathrm{A}^{\mathrm{pr}}\right)\end{array}$ \\
\hline $10-11$ & 8 & 37 & 2.77 & 3.18 & 0.63 & 0.81 & 0.11 & 65 & 0.00 \\
$11-12$ & 30 & 58 & 3.22 & 2.99 & 0.50 & 0.78 & 0.11 & 90 & 0.17 \\
$12-13$ & 10 & 49 & 2.72 & 3.20 & 0.64 & 0.86 & 0.00 & 72.5 & 0.05 \\
$13-14$ & 30 & 55 & 3.05 & 3.19 & 0.59 & 0.86 & 0.05 & 80 & 0.22 \\
$14-15$ & 8 & 44 & 2.44 & 2.87 & 0.42 & 0.54 & 0.00 & 45 & 0.00 \\
Mean & - & - & 2.84 & 3.09 & 0.56 & 0.77 & - & - & - \\
SD & - & - & 0.30 & 0.14 & 0.09 & 0.13 & - & - \\
\hline
\end{tabular}

P- polymorphism, SD- standard deviation.

TABLE 4: Genetic diversity of landraces of Pearl millet according to geographic origin.

\begin{tabular}{lccccccccc}
\hline Region & $\begin{array}{c}\text { Accession } \\
\text { number }\end{array}$ & $\begin{array}{c}\text { Allele number } \\
\left(\mathrm{A}^{\mathrm{t}}\right)\end{array}$ & $\begin{array}{c}\text { Allele number/ } \\
\text { marker }\end{array}$ & $\begin{array}{c}\text { Efficient allele } \\
\left(\mathrm{A}_{\mathrm{e}}\right)\end{array}$ & $\begin{array}{c}\text { Gene diversity } \\
(\mathrm{He})\end{array}$ & $\begin{array}{c}\text { Shannon index } \\
(\mathrm{I})\end{array}$ & $\begin{array}{c}\text { PIC } \\
(\%)\end{array}$ & $\begin{array}{c}\text { Rare allele } \\
\left(\mathrm{A}^{\mathrm{r}}\right)\end{array}$ \\
\hline East & 10 & 46 & 2.55 & 3.18 & 0.61 & 0.82 & 0.67 & 67.5 & 0 \\
North & 36 & 56 & 3.11 & 3.09 & 0.55 & 0.84 & 0.63 & 92.5 & 5 \\
West & 7 & 49 & 2.72 & 2.75 & 0.37 & 0.48 & 0.55 & 40 & 0 \\
South & 33 & 60 & 3.33 & 3.29 & 0.62 & 0.90 & 0.71 & 80 & 2 \\
Mean & - & - & 2.93 & 3.08 & 0.54 & 0.76 & 0.64 & - & - \\
SD & - & - & 0.35 & 0.23 & 0.11 & 0.18 & 0.06 & - & - \\
\hline
\end{tabular}

P- polymorphism, SD- standard deviation, PIC- polymorphism information content.

TAвLE 5: $\mathrm{F}_{\mathrm{ST}}$ matrix evaluations (below the diagonal) and Nei genetic distances (above the diagonal) between different latitudes.

\begin{tabular}{lcccc}
\hline FST & & & Distance of Nei & $13^{\circ}-14^{\circ}$ \\
\hline $10^{\circ}$ & $10^{\circ}-11^{\circ}$ & $11^{\circ}-12^{\circ}$ & $12^{\circ}-13^{\circ}$ & 0.094 \\
$11^{\circ}$ & & 0.049 & 0.087 & 0.196 \\
$12^{\circ}$ & $-0.023 \mathrm{~ns}$ & & 0.036 & 0.170 \\
$13^{\circ}$ & $-0.024 \mathrm{~ns}$ & $0.002 \mathrm{~ns}$ & & 0.022 \\
$14^{\circ}$ & $-0.011 \mathrm{~ns}$ & $0.006 \mathrm{~ns}$ & $0.007 \mathrm{~ns}$ & 0.180 \\
\hline
\end{tabular}

TAвLE 6: $\mathrm{F}_{\mathrm{ST}}$ matrix evaluations (below the diagonal) and Nei genetic distances (above the diagonal) between different regions.

\begin{tabular}{lcccr}
\hline FST & \multicolumn{3}{c}{ Distance of Nei } \\
\hline East & & 0.039 & 0.120 & 0.081 \\
North & $0.005 \mathrm{~ns}$ & & 0.053 & 0.048 \\
West & $-0.017 \mathrm{~ns}$ & $-0.008 \mathrm{~ns}$ & 0.063 \\
South & $-0.008 \mathrm{~ns}$ & $0.011 \mathrm{~ns}$ & $-0.0004 \mathrm{~ns}$ & \\
\hline
\end{tabular}

TABLE 7: Average genetic similarity index of cultivars between the different latitudes of Burkina Faso.

\begin{tabular}{lccccc}
\hline Latitudes & $10^{\circ}-11^{\circ}$ & $11^{\circ}-12^{\circ}$ & $12^{\circ}-13^{\circ}$ & $13^{\circ}-14^{\circ}$ & $14^{\circ}-15^{\circ}$ \\
\hline $10^{\circ}$ & 1 & $0.952^{* *}$ & $0.916^{* *}$ & $0.910^{* *}$ & $0.822^{* *}$ \\
$11^{\circ}$ & & 1 & $0.964^{* *}$ & $0.958^{* *}$ & $0.844^{* *}$ \\
$12^{\circ}$ & & & 1 & $0.978^{* *}$ & $0.835^{* *}$ \\
$13^{\circ}$ & & & & 1 & $0.897^{* *}$ \\
$14^{\circ}$ & & & & & 1 \\
\hline
\end{tabular}

accessions of the $\mathrm{C} 1$ subgroup include accessions from the north, west, and south that are mostly early. In addition, the C2 subgroup is made up only of accessions from the north and south. The C3 subgroup includes accessions from all regions in which late, semiearly, and early accessions are found.
3.6. Genetic Cluster Analysis of Landraces. The level of diversity of the three identified genetic groups is given in Table 9. Indeed, genetic groups B and C show higher levels of diversity than the population of genetic group A for the heterozygosity rate parameter $(\mathrm{He})$, while the latter has the best allelic richness than either of the two groups. Thus, the analysis of genetic diversity at the allelic level of each genetic population through the diversity indices is as follows:

(i) Genetic group A contains 39 alleles on average, an average expected heterozygosity $(\mathrm{He})$ of 0.41 , and a polymorphism rate of about $67 \%$. This genetic group with its allelic richness represents $42.85 \%$ of the allelic diversity within the total population. Only $5.1 \%$ of the alleles are specific for this genetic group. Genetic group A appears to be less heterogeneous than the other two genetic groups, although it is 
TABLE 8: Average genetic similarity index of cultivars between the different regions of Burkina Faso.

\begin{tabular}{lcccc}
\hline Geographic regions & East & North & West & South \\
\hline East & 1 & $0.962^{* *}$ & $0.887^{* *}$ & $0.922^{* *}$ \\
North & & 1 & $0.949^{* *}$ & $0.953^{* *}$ \\
West & & & 1 & $0.939^{* *}$ \\
South & & & 1 \\
\hline
\end{tabular}

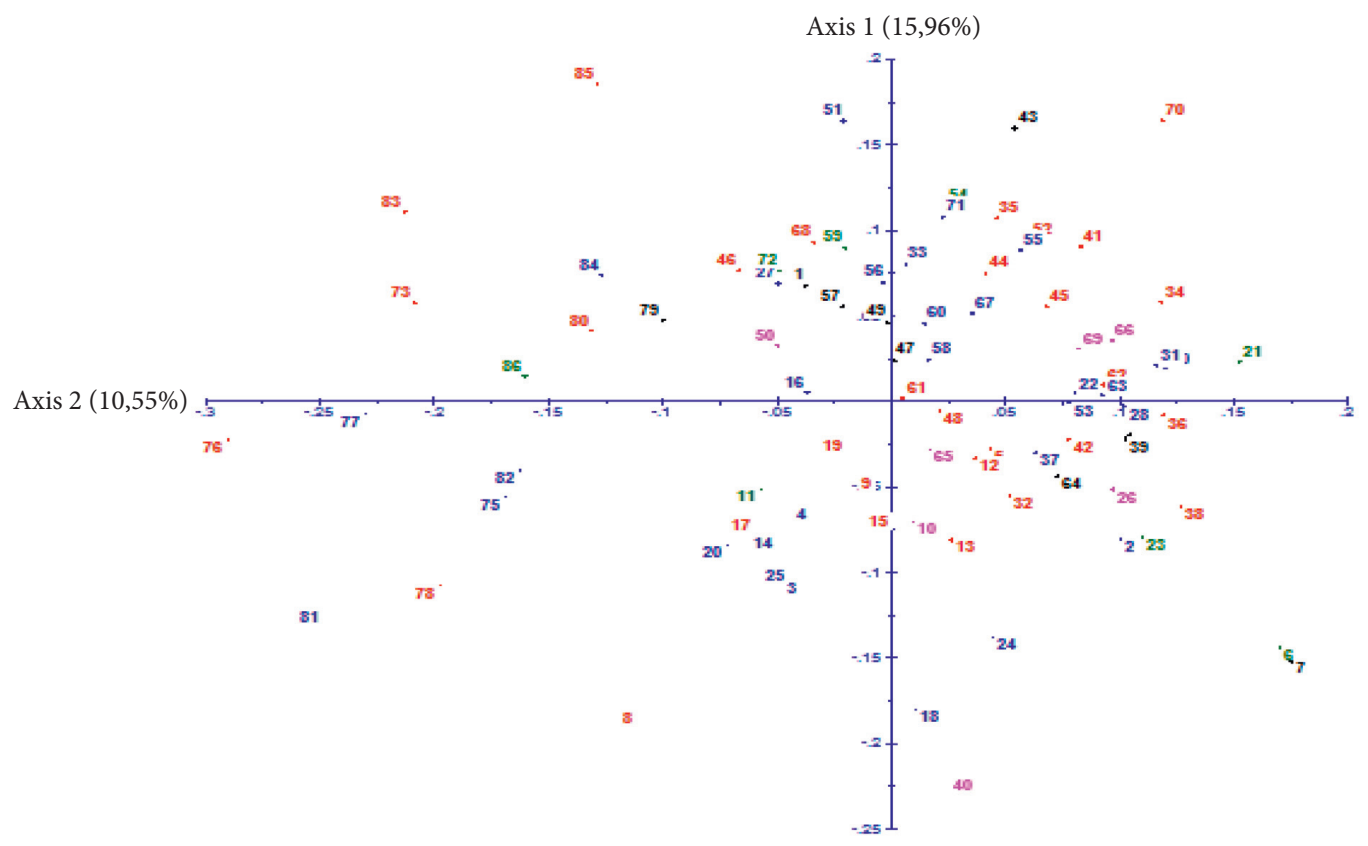

Figure 3: Principal component analysis of accessions from five different degrees of latitudes based on Euclidean distance estimates. $10^{\circ}$ : green; $11^{\circ}$ : blue; $12^{\circ}$ : black; $13^{\circ}$ : red; and $14^{\circ}$ : pink.

poorly represented in cultivated pearl millet populations.

(ii) Genetic group B indicates 53 alleles on average, an expected heterozygosity $(\mathrm{He})$ of 0.80 , and a polymorphism rate of around $85 \%$. Its allelic diversity corresponds to $71.43 \%$ among the general population studied. This genetic group was the one that presented the rarest alleles ( 7 alleles) but the lowest PIC (0.55) and, therefore, presents less allelic richness compared to the other genetic groups. In this genetic group, some alleles are likely to disappear more rapidly.

(iii) Genetic group $\mathrm{C}$ has the largest number of alleles (62 alleles) with an average expected heterozygosity (He) of 0.86 , a polymorphism rate of $87 \%$, and a PIC of 0.61 . It appears as the genetic group with the highest contribution to the total allelic diversity with $89.80 \%$. This population was fundamentally heterogeneous and is made of a mixture of genotypes from all geographical regions. We find $20.97 \%$ of specific alleles for this genetic group.

3.7. Genetic Organization. Table 10 presents the minimum Nei distance between pairs of genetic groups of the populations. It was observed the population of genetic group $B$ is at intermediate genetic distance $(0.041$ and 0.042$)$ from genetic group $\mathrm{A}$ and genetic group $\mathrm{C}$, respectively. The most genetically distant groups (0.660) were genetic group A and genetic group C. Genetic distances estimated between populations (FST) showed a $p$ value 0.016 after 300 permutations. The coefficient of genetic differentiation (Gst) between populations was 0.46 . These reveal the plausible existence of allelic substitutions occurred during the evolution of three populations after their differentiation.

\section{Discussion}

4.1. Pearl Millet Landrace Genetic Diversity. The frequency of heterozygotes averaged for two different alleles is high. It reveals that the majority loci show polymorphism to be accounted for by selection-mutation balance. However, polymorphism differs also for different kinds of trait because polymorphism is found in almost all natural populations and occurs at all levels of genetic organization, from DNA sequences to major morphological traits. Polymorphism is considered as the source of the variation of quantitative characters and is a fundamental interest to the selection. In another studies with pearl millet taxonomic groups, frequencies of heterozygotes of 0.77 and 0.74 , respectively, were reported $[6,19]$. The frequency of heterozygote remains high in cultivated pearl millet populations that coexist with wild forms. There are, however, difficulties 


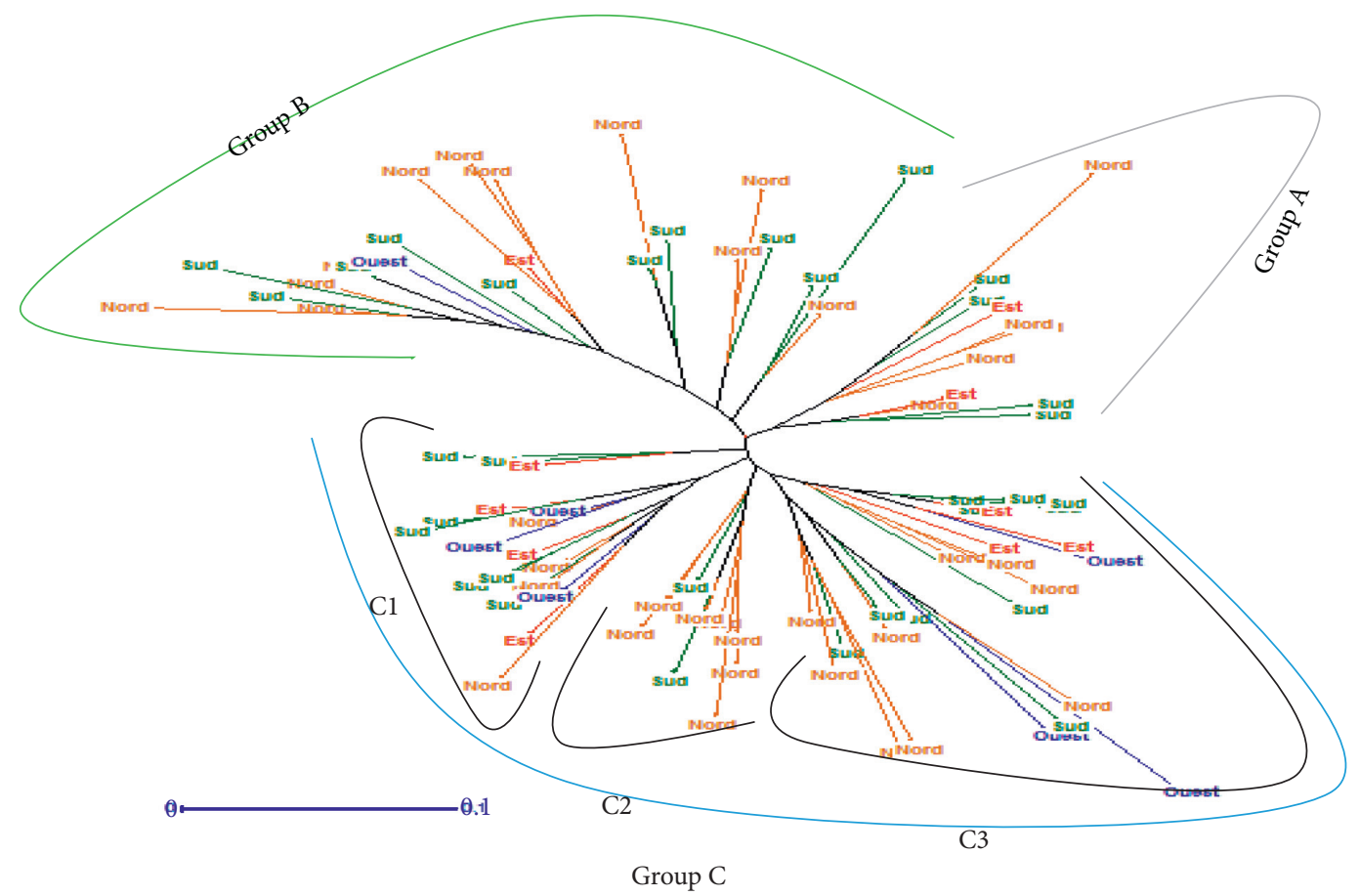

FIGURE 4: Dendrogram constructed using the neighbor-joining algorithm from the dissimilarity matrix between landraces in Burkina Faso, based on microsatellite markers.

TABLE 9: Level of intrapopulation diversity of pearl millet in Burkina Faso.

\begin{tabular}{lccccccccccc}
\hline Genetic group & Acc. nu & $\mathrm{A}^{\mathrm{t}}$ & Allele/marker & $\mathrm{A}^{\text {rich }}$ & $\mathrm{A}_{\mathrm{e}}$ & $\mathrm{He}$ & $\mathrm{I}$ & $\mathrm{PIC}^{\mathrm{P}}$ & $\mathrm{P}_{(\%)}$ & $\mathrm{A}^{\mathrm{r}}$ & $\mathrm{A}^{\mathrm{pr}}$ \\
\hline $\mathrm{A}$ & 10 & 39 & 2.16 & 3.12 & 2.82 & 0.41 & 0.58 & 0.64 & 67.5 & 0 & 0 \\
$\mathrm{~B}$ & 22 & 53 & 2.94 & 1.66 & 3.10 & 0.80 & 0.80 & 0.55 & 85 & 7 & 2 \\
$\mathrm{C}$ & 54 & 62 & 3.44 & 1.15 & 3.14 & 0.86 & 0.86 & 0.61 & 87.5 & 3 & 2 \\
Mean & - & - & 2.85 & 1.98 & 3.02 & 0.69 & 0.74 & 0.60 & - & - & - \\
SD & - & - & 0.64 & 1.02 & 0.17 & 0.24 & 0.14 & 0.04 & - & - & - \\
\hline
\end{tabular}

TABLE 10: Estimates of $\mathrm{F}_{\mathrm{ST}}$ matrices (below the diagonal) and Nei genetic distances (above the diagonal) between genetic groups.

\begin{tabular}{lcccc}
\hline \multirow{2}{*}{ FST } & \multicolumn{4}{c}{ Distance of nei } \\
& A & B & C & Gst \\
\hline A & & 0.041 & 0.660 & \\
B & $0.2484^{*}$ & & 0.042 & $\mathbf{0 . 4 6}$ \\
C & $0.1344^{*}$ & $0.2097^{*}$ & & \\
\hline
\end{tabular}

connected with the effects of inbreeding and with the genetic load incurred if very many loci are kept polymorphic by heterozygote advantage. The genetic erosion of wild forms due to anthropogenic actions reduces the genetic diversity of pearl millet cultivated. Todays, low level of genetic diversity of pearl millet cultivated in sub-Sahelian Africa could be attributed climatic shift and variations and biotic constraints. The genetic erosion of cultivated species in several countries of sub-Saharan Africa is increasing in the context of climate change according to the work in [20].

Allelic diversity of millet populations from rural farmers is low compared to the allelic diversity reported in $[6,13]$, using the same markers, where a high average number of alleles per locus was observed.
Indeed, in $[6,13]$, an average number of alleles per locus of 9.6 and 13.3, respectively, was found. Pearl millet collected from Mali and Niger on the one hand and Sudan on the other hand was used, which are centers of primary pearl millet origin $[21,22]$. This could explain why the genetic base of pearl millet grown in Burkina Faso is narrowing. Indeed, allelic richness constitutes a source of evaluation of genetic diversity as revealed in $[23,24]$. It was considered that the preservation of the alleles of a species is more important than the maintenance of allelic frequencies. However, the allelic richness of pearl millet populations for the case of this collection is also comparable to that in $[6,13]$.

Based on the concepts related to the polymorphism of a population, the polymorphism rate obtained in our collection showed a proportion of locus quite polymorphic but lower than that in [6]. This rate is higher than that obtained in [5]. Maintaining such a high frequency of secondary alleles above $20 \%$ explains a still low level of inbreeding in the study population. This suggests a high potential for obtaining heterosis of interest.

4.2. Regional Genetic Diversity. Although environmental conditions are highly variable in the geographic regions of 
the country, the genetic variation of pearl millet between regions shows a nonsignificant difference. This genetic diversity has resulted in a significant number of common alleles among the geographical regions. Previous studies based on enzyme markers have shown that the ecotypes of the central, south central, and eastern regions form predominantly homogeneous groups [25]. The present genetic diversity shows that total genetic diversity can be obtained from two geographical regions of the country, indicating a high rate of new allopatric populations simply following exchanges of accessions between different regions and climate change. A majority of common alleles were identified between accessions from different geographical regions revealing the low allelic diversity between traditional cultivated varieties. In general, the high allogamy of pearl millet $(85 \%)$ is a source of genetic similarity between accessions as well as farmers' practices for those reported in $[19,26]$. This high similarity of our accessions is explained by interfertility, which is the preferred mode of reproduction of millet. This high similarity between accessions is explained by the permanent exchange of seeds between farmers in different geographical regions.

The fact that traditional seed varieties circulate among farmers through inheritance and donation means that the same varieties are found in several growing areas. According to the work in [27], rural populations take their seeds with them when they move to other growing areas. This analysis of the nonsignificant difference between geographical regions was also revealed in Sudan in [6], thus showing that the structuring of genetic diversity of pearl millet populations is independent of geographical regions. The work in $[5,26]$ justifies the low level of genetic differentiation in pearl millet by gene flow and seed sharing among farmers. In contrast, in [19], it was shown that the similarity of accessions between geographical regions is linked to high climatic variability leading to selection pressures and over time narrows genetic diversity. Rural farmers tend to select crops varieties for agronomic and resistance performance criteria at the expense of conservation of genetic resource. In the phenotypic characterization, it was observed in each geographical region that the different varieties are identified by their morphological and phenological traits. However, these morphological differences do not seem to have as a corollary a great genetic difference between the accessions. These same observations were reported in [28].

4.3. Genetic Organization. Genetic differentiation between accessions was found to be much more important than that between geographic regions as evidenced by the number of groups and subgroups shown by the neighbor-joining tree. The pearl millet populations appear to form a single gene pool given their small genetic distance. This corroborates with the studies in [25] which revealed a single group with the use of biochemical markers. Molecular markers have been shown to be more informative in genetic diversity studies than enzymatic markers and are more conclusive in a conservation study of plant genetic resources and related species. The genetic diversity structure of the accessions showed three different populations with a classification that does not contain geographical regions. This constitutes a source for the development of heterosis cultivars to increase productivity and their resilience to climatic variability. The average values of the genetic diversity of each of the genetic groups obtained indicate that each population is rich in heterozygotes. Our results reveal the existence of three racial pearl millet populations.

However, this group structuring may still be influenced by the markers used, the sample size, and the geographic distances of the accessions revealed in [29]. With this level of observed genetic diversity, a collection plan to build a core collection would be an option to support breeding programs for this species. The presence of northern accessions in all genetic groups would be explained by population migrations from one area to another on the one hand and cultural and ethnic factors on the other hand. The work in [27, 30] revealed that rural populations take their seeds with them when they move from Sahelian to Sudanese zones. Before, the work in [25] attributed the diversity of the northern ecotypes to their proximity to Nigerian millets, which were recognized as the most varied and diverse in the Sahelian zone.

\section{Conclusions}

The study revealed the existence of a relatively low genetic diversity within the landraces studied. Twenty markers were used of which eighteen were polymorphic. The structuring of the genetic diversity revealed three genetic groups cultivated in the country. This indicates that this diversity can be used in a breeding program. However, genetic group $\mathrm{C}$ groups the maximum number of landraces with a broad genetic base. The genetic differentiation obtained shows that millets are not grouped according to a geographic system but rather on the basis of factors related to selection pressure, environmental constraints, and anthropogenic factors.

\section{Data Availability}

The data used to support the findings of this study are available from the corresponding author upon request.

\section{Disclosure}

This research is part of a Ph.D. thesis called "Etude de la diversité génétique des populations de mil [Pennisteum glaucum (L.) R.Br.] cultivées au Burkina Faso dans le contexte du changement climatique" [31].

\section{Conflicts of Interest}

The authors declare no conflicts of interest regarding the publication of this paper.

\section{Authors' Contributions}

This work was carried out in collaboration between both authors. The first author designed the experiment and 
analyzed the data. Both of the authors interpreted the data, read the final manuscript, and agreed with all contents.

\section{Acknowledgments}

The authors gratefully acknowledge the Biosciences Laboratory of the Joseph KI-ZERBO University for the financial support for the experiment and the input in this manuscript.

\section{References}

[1] A. Bougma, G. Galluzzi, and M. Sawadogo, "The importance of international exchanges of plant genetic resources for national crop improvement in Burkina Faso. CCAFS Working Paper no. 152. CGIAR Research Program on Climate Change, Agriculture and Food Security (CCAFS). Copenhagen, Denmark," 2015, http://www.ccafs.cgiar.org.

[2] FAOSTAT, Production Data, 2014, http://faostat3.fao.org/ browse/Q/QC/E.

[3] S. Tosiain, M. F. Riandey, and L. Marchais, "Enzyme diversity in pearl millet (Pennisetum glaucum)," Theoretical and Applied Genetics, vol. 74, pp. 188-193, 1987.

[4] C. IBPGR Dib, S. Faure, C. Fizames et al., "A comprehensive genetic map of the human genome based on 5,264 microsatellites," Nature, vol. 380, pp. 152-154, 1996.

[5] C. Mariac, V. Luong, I. Kapran et al., "Diversity of wild and cultivated pearl millet accessions (Pennisetum glaucum [L.] R. Br.) in Niger assessed by microsatellite markers," Theoretical and Applied Genetics, vol. 114, no. 1, pp. 49-58, 2006.

[6] E. M. A. Bashir, A. M. Ali, A. M. Ali et al., "Genetic diversity of Sudanese pearl millet (Pennisetum glaucum (L.) R. Br.) landraces as revealed by SSR markers, and relationship between genetic and agro-morphological diversity," Genetic Resources and Crop Evolution, vol. 62, no. 4, pp. 579-591, 2014.

[7] C. A. Stockwell, A. P. Hendry, and M. T. Kinnison, "Contemporary evolution meets conservation biology," Trends in Ecology \& Evolution, vol. 18, no. 2, pp. 94-101, 2003.

[8] D. Mingeot and B. Watillon, "Authentification variétale par marqueurs moléculaires," Journée d'étude Pomme de Terre $C R A-W$, vol. 3, 2005.

[9] S. Allouis, X. Qi, S. Lindup, M. D. Gale, and K. M. Devos, "Construction of a BAC library of pearl millet, Pennisetum glaucum," Theoretical and Applied Genetics, vol. 102, pp. 1200-1205, 2000.

[10] X. Qi, S. Lindup, T. S. Pittaway, S. Allouis, M. D. Gale, and K. M. Devos, "Development of simple sequence repeat markers from bacterial artificial chromosomes without subcloning," Biotechniques, vol. 31, no. 2, pp. 355-362, 2001.

[11] H. Budak, F. Pedraza, P. B. Cregan, P. S. Baenziger, and I. Dweikat, "Development and utilization of SSRs to estimate the degree of genetic relationships in a collection of pearl millet germplasm," Crop Science, vol. 43, no. 6, pp. 2284-2290, 2003.

[12] L. Bougma, M. Ouédraogo, N. Sawadogo, and M. Sawadogo, "Climate change effect on pearl millet [Pennisetum glaucum (L.) R. Br.] genetic variability in Burkina Faso," American Journal of Experimental Agriculture, vol. 12, no. 4, pp. 1-11, 2016.

[13] I. Oumar, C. Mariac, JL. Pham, and Y. Vigouroux, "Phylogeny and origin of pearl millet (Pennisetum glaucum [L.] R. Br) as revealed by microsatellite loci," Theoretical and Applied Genetics, vol. 117, no. 4, pp. 489-497, 2008.
[14] C. Agbangla, S. Tostain, A. Dansi, and O. Daïnou, "Evaluation de la diversité génétique par RAPD d'un échantillon de dioscorea alata d'une région du bénin, la sous préfecture de savè," Journal de la Recherche Scientifique de l'Universite de Lome, vol. 6, no. 1, pp. 197-202, 2002.

[15] J. A. Anderson, G. A. Churchill, J. E. Autrique, S. D. Tanksley, and M. E. Sorrells, "Optimizing parental selection for genetic linkage maps,” Genome, vol. 36, no. 1, pp. 181-186, 1993.

[16] M. Nei, Molecular Evolutionary Genetics, Columbia University Press, New York, NY, USA, 1987.

[17] B. S. Weir and C. C. Cockerham, "Estimating F-statistics for the analysis of population structure," Evolution, vol. 38, no. 6, pp. 1358-1370, 1984.

[18] M. Nei, "Analysis of gene diversity in subdivided populations," Proceedings of the National Academy of Sciences, vol. 70, no. 12, pp. 3321-3323, 1973.

[19] B. Stich, B. I. G. Haussmann, P. Raj et al., "Patterns of molecular and phenotypic diversity in pearl millet [Pennisetum glaucum (L.) R. Br.] from West and Central Africa and their relation to geographical and environmental parameters," BMC Plant Biology, vol. 10, pp. 1-10, 2010.

[20] FAO, Changement Climatique et Biodiversité Pour L'Alimentation et L'Agriculture, FAO, Rome, Italy, 2008, http:// www.fao.org/foodclimate.

[21] J. R. Harlan, Crops and Man, American Society of Agronomy and Crop Science Society of America, Madison, WI, USA, 1975.

[22] R. Porteres, "African cereals: eleusine, fonio, black fonio, teff, Brachiaria, Paspalum, Pennisetum and African rice," in Origins of African Plant Domestication, J. Harlan, J. De Wet, and A. Stemler, Eds., Mouton Publishers, La Hague, France, 1976.

[23] A. Kremer, "Diversité génétique et variabilité des caractères phénotypiques chez les arbres forestiers," Genetics Selection Evolution, vol. 26, no. 1, pp. 105s-123s, 1994.

[24] A. El Mousadik and R. J. Petit, "High level of genetic differentiation for allelic richness among populations of the argan tree [Argania spinosa (L.) Skeels] endemic to Morocco," Theoretical and Applied Genetics, vol. 92, no. 7, pp. 832-839, 1996.

[25] D. Balma, "Étude de la variabilité génétique du mil (Pennisetum typhoides, Stapf et Hubbard). Implication concernant la conservation et l'utilisation des ressources phytogénétiques," Faculté des Sciences de l'Agriculture et de l'Alimentation/ Université Laval, Québec, Canada, Thèse de doctorat (Ph.D.), 1992.

[26] K. Vom Brocke, A. Christinck, R. E. Weltzien, T. Presterl, and H. H. Geiger, 'Farmers' seed systems and management practices determine pearl millet genetic diversity patterns in semiarid regions of India," Crop Science, vol. 43, no. 5, pp. 1680-1689, 2003.

[27] N. Sawadogo, "Etude diversité génétique des sorghos à grains sucrés [Sorghum bicolor (L.) Moench] du Burkina Faso," Université de Ouagadougou, Ouagadougou, Burkina Faso, Mémoire Thèse Doctorat Unique, 2015.

[28] C. S. Busso, K. M. Devos, G. Ross et al., "Genetic diversity within and among landraces of pearl millet (Pennisetum glaucum) under farmer management in West Africa," Genetic Resources and Crop Evolution, vol. 47, no. 5, pp. 561-568, 2000.

[29] N. A. Rosenberg, S. Mahajan, S. Ramachandran, C. Zhao, J. K. Pritchard, and M. W. Feldman, "Clines, clusters, and the effect of study design on the inference of human population structure," PLoS Genetics, vol. 1, no. 6, p. e70, 2005. 
[30] T. Robert, A. Luxereau, C. Mariac et al., "Influence des facteurs anthropiques et des flux de gènes sur la variabilité génétique des formes cultivées et spontanées du mil dans deux localités du Niger," in Ressources Génétiques des Mils en Afrique de l'Ouest. Diversité, Conservation et Valorisation, G. Bezançon and J. L. Pham, Eds., IRD Éditions, Marseille, France, 2004.

[31] L. A. Bougma, "Etude de la diversité génétique des populations de mil [Pennisteum glaucum (L.) R.Br.] cultivées au Burkina Faso dans le contexte du changement climatique," Université Ouaga I Joseph Ki-Zerbo, Ouagadougou, Burkina Faso, Mémoire Thèse Doctorat unique, 2017. 